\title{
舌転移をきたした腎細胞癌例
}

-QOL 改善のための手術一

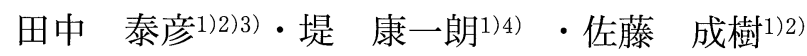 \\ 鈒持 睦122)5) ・ 大橋 徹1)266) ・肥塚 泉 ${ }^{11}$
}

\section{A Case of Renal Carcinoma Metastatic to the Tongue}

\author{
Yasuhiko Tanaka \\ (St. Marianna University School of Medicine, St. Marianna University School of \\ Medicine Yokohama City Seibu Hospital, Yokohama General Hospital) \\ Kouichiro Tsutsumi \\ (St. Marianna University School of Medicine, Kawasaki Municipal Tama Hospital)

$$
\text { Shigeki Sato }
$$ \\ (St. Marianna University School of Medicine, St. Marianna University School of \\ Medicine Yokohama City Seibu Hospital)

\section{Mutsumi Kenmochi} \\ (St. Marianna University School of Medicine, St. Marianna University School of \\ Medicine Yokohama City Seibu Hospital, Mutsumi Clinic)

\section{Toru Ohashi} \\ (St. Marianna University School of Medicine, St. Marianna University School of \\ Medicine Yokohama City Seibu Hospital, Hadano Red Cross Hospital)

\section{Izumi Koizuka}

(St. Marianna University School of Medicine)

We report a case of renal cell carcinoma metastatic to the tongue. An 82-year-old man presented with a tumor measuring $13 \times 10 \mathrm{~mm}$ at the right border of the tongue. He had a history of renal cell carcinoma, and had undergone right radical nephrectomy in 1988. He also had multiple metastatic lesions to both lung and brain. He was hospitalized in 2002, and his chief complaint was mastication disorder. In order to improve his quality of life, the tumor of the tongue was resected under local anesthesia, and he could ingest food after the resection. The resected specimen showed renal cell carcinoma. We conclude that if the metastatic tongue lesion is resectable without severe disturbance of function or form, occasional cure can be effected by surgical resection.

Key words : renal cell carcinoma, metastatic tumor, tongue

1）聖マリアンナ医科大学耳鼻咽喉科

3）横浜総合病院耳鼻咽喉科

5）耳鼻咽喉科むつみクリニック（横浜市）
2）聖マリアンナ医科大学横浜市西部病院

4）川崎市立多摩病院耳鼻咽喉科

6）秦野日本赤十字病院耳鼻咽喉科 


\section{はじめに}

頭頸部外科領域では，頸部リンパ節以外への他藏器原 発の悪性腫瘍の転移は比較的少ないとされている。今回 われわれは，腎細胞癌の舌転移により咀嚼障害をきたし たため外科的切除を行い, QOL の改善が得られた 1 症例 を経験したので報告する。

\section{症例}

患者： 82 歳, 男性.

主訴：咀嚼障害.

家族歴：特記すべきことなし。

既往歴：特記すべきことなし。

現病歴：昭和 63 年他院にて腎細胞癌と診断され, 右腎 摘出術施行した。平成 7 年 12 月, 聖マリアンナ医科大学 横浜市西部病院呼吸器内科を受診した。この時点で多発 性肺転移を認めた。平成 8 年 2 月 7 日より同病院泌尿器 科にて，腎細胞癌肺転移に対し，インターフェロン療法 を行いながら外来にて加療していた。平成 14 年 7 月, 全 身精査のため頭部 CT を施行したところ，多発性の脳転 移が認められた。全身状態の低下も徐々に認められてい た。平成 14 年 9 月, 舌右側縁に無痛性の腫瘤を自覚して いた。徐々に増大し，咀嚼障害をきたし栄養状態の低下 を認めた。咬傷による出血をきたしたため平成 14 年 10 月 23 日泌尿器科に入院となり, 平成 14 年 11 月 22 日, 同病院耳鼻咽喉科紹介受診となった。

初診時所見: 舌右側縁に柔らかい隆起性腫瘤を認めた。 表面平滑で暗赤色を呈していたが，易出血性ではなかっ た。頸部に腫瘤は触知せず，その他耳鼻咽喉科領域に病 変は認めなかった。開口および舌の運動に異常は認めな 加た。

検查所見: WBC $17200 / \mu 1, \mathrm{RBC} 430 \times 10^{4} / \mu \mathrm{l}, \mathrm{Hgb} 14.4 \mathrm{~g} /$ dl, BUN $49.0 \mathrm{mg} / \mathrm{dl}, \quad$ Cr $1.50 \mathrm{mg} / \mathrm{dl}, \quad$ CRP $15.7 \mathrm{mg} / \mathrm{dl}$. その他, 血液生化学検查上異常を認めなかった。

経過：咀嚼障害による栄養状態の改善を目的として, 平成 14 年 11 月 26 日, 舌腫瘍摘出術を行った。術前所見 として, 舌右側縁に $1.3 \times 1.0 \mathrm{~cm}$ の隆起性腫瘤を認め, 表面は一部潰陽状を呈していた（図 1)。摘出術は局所麻 酔で行い，腫瘤の深部は筋層との癒着や浸潤は認めず， 術中深部出血も少なく, 肉眼的に正常な組織を十分含め て摘出した後, KTPレーザーにて創面を焼灼し縫合した。 術後経過は良好で，術後第 2 病日より流動食から経口摂 取を開始した。

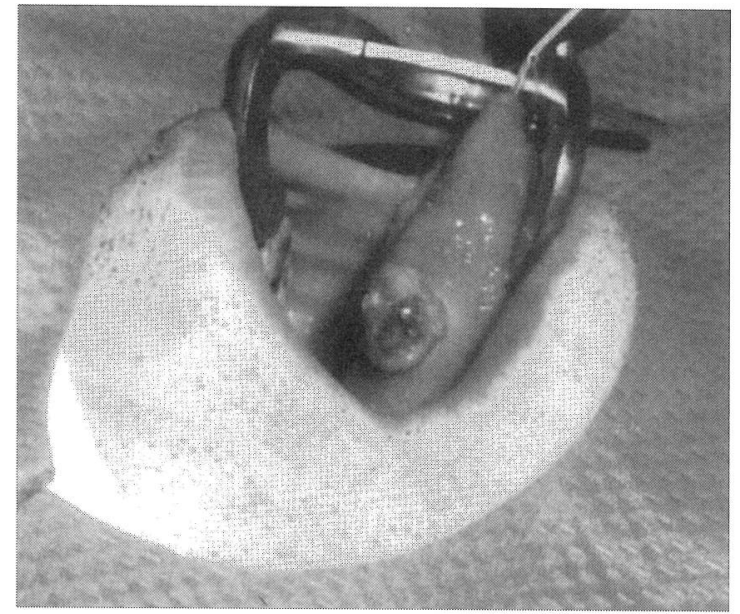

図 1 術前所見

舌右側縁に隆起性腫瘤を認める。腫瘤は一部潰瘍状を呈 している.

病理組織学的所見：弱拡大では重層扁平上皮の下層に 明細胞を認める（図 $2 \mathrm{a}$ ）。

強拡大では，標本作製の過程で細胞内に多く含まれる グリコーゲン，脂肪が溶出するため明るく抜けた細胞質 を呈する明細胞が認められ，間質には毛細血管網の発達 が明瞭に認められた。これらは，細い血管結合織に境さ れ，小さい胞巣を形成していた。増殖は管状汃ら乳頭状 で線維成分に乏しく，類洞様の毛細血管と密に接してい た（図 $2 \mathrm{~b})$.

以上より組織学的に腎細胞癌の舌転移と䛦断したた め, 頭頸部領域の精查のため術後 7 日目に MRI 画像検査 を施行したが，境界明瞭で内部構造の不均一な高信号の 腫崵を副咽頭間隙に認め，他部位の経過加考光るとこ れも腎細胞癌からの転移ではないかと考えた（図 3) が, 患者の全身状態，QOL を考慮し細胞診，外科的処置等は 行わなかった。経口摂取に関しては最終的には，全獭を 摂取できるまでに改善したが，徐々に全身状態の低下を 認め, 平成 15 年 2 月 11 日に死亡した。

\section{考察}

腎細胞癌は腎癌の一形態で, 尿細管上皮より発生する. 60歳前後の男性に好発する癌で性比では男性に多く女性 の 2 ～ 3 倍で，腎腫瘍の $70 \sim 80 \%$ を占め，悪性腎腫瘍 の $90 \%$ を占める。こ秃は腎に発生する腫瘍の中で最む多 い。臨床的には，無症候性血尿を初発症状とすることが 


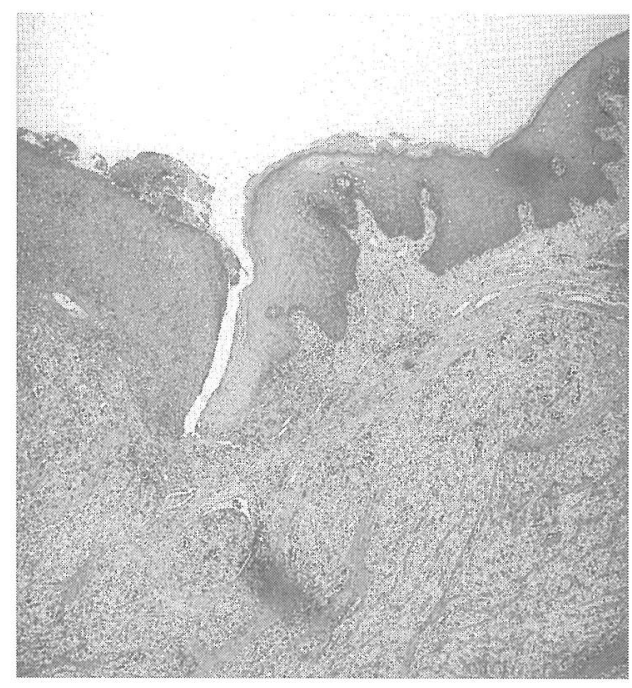

a

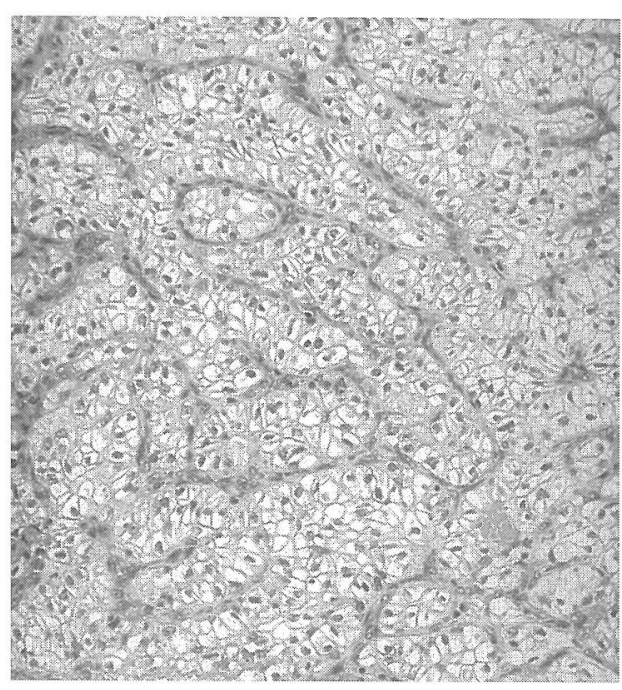

b

図 2 病理学的所見 (HE 染色, a : 1 倍, b : 20 倍)

$\mathrm{a}$ 弱拡大では重層扁平上皮の下層に明るく抜けた細胞質を呈する明細胞を認める.

b 強拡大では明細胞吕認められ，間質には毛細血管網の発達が明膫に認められた。 以上の所見は腎細胞癌に矛盾しない像であっ た.

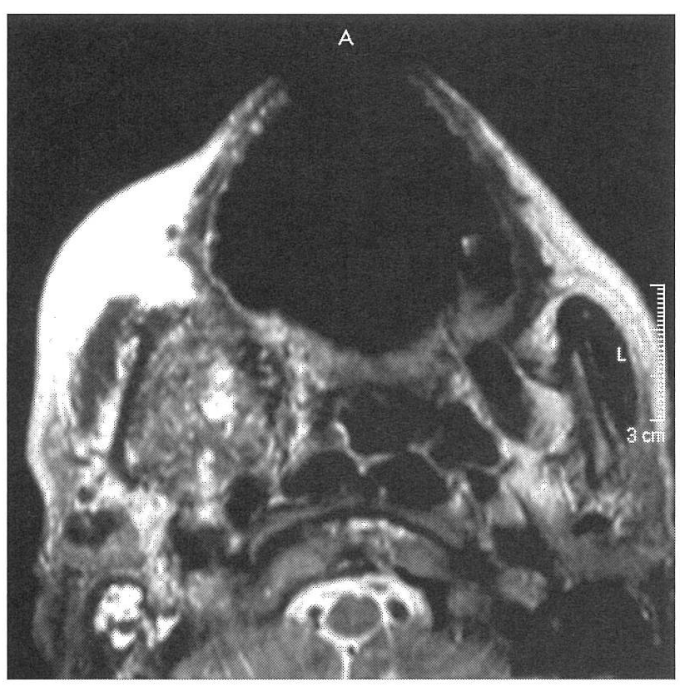

図 3 MRI 画像所見

$\mathrm{T} 2$ 強調画像では境界明瞭で内部構造の不均一な高信号の 腫瘍を副咽頭閒隙に認めた。経過から考えるとこれも腎 細胞癌からの転移ではないかと考えた。

多い，進展したものでは腰痛や拍動性に腫瘍を触れるよ らになる。ときに上皮小体あるいはエリスロポエチン様 のホルモンを産生するようにもなる，癌が進行し，腎静 脈内に浸潤すると連続的に心房内に達することもある.
また, 比較的早期办ら他臓器へ転移しやすく, 肺, リン パ節，骨，肝，対側腎，副腎，脳，脾などにも転移する。 本症例でも舌の他，肺，脳に転移を認めていた。

WHO 分類（1998 年）によると腎細胞癌は, 組織学的に は明細胞癌，顆粓細胞癌，嫌色素細胞癌，紡鍾細胞癌， 囊胞随伴性腎細胞癌，乳頭状腎細胞癌に大別される。本 症例の舌切除標本では，細胞質の明るい明細胞を認め, 臨床経過も含め腎細胞癌の転移として矛盾のない像で あった。また病理学的には，腫瘍細胞には，エオジンに 染まる顆粒に富んだ顆粒細胞型，両者の混合型，肉腫様 を示すものもあるが，乳頭状あるいはエオジン好性顆粒 状細胞で構成されるものは予後がよいとされている。

腎細胞癌の転移は大部分が血行性転移であり，腎静脈 から卵巣または精栄静脈から逆行性に骨盤臟器に転移す るもの, Batson 椎骨静脈叢加骨格へ転移するもの，下 大静脈少ら肺へ転移し，さらに左心室加ら動脈を介する むのもある，リンパ行性転移は，所属リンパ節にとどま るものが多い。

頭頸部領域にお打腎細胞癌の転移に関して, Zegarelli1）らによると悪性腫瘍剖検例のうち舌への転移 は, 6881 症例中 15 例で約 $0.2 \%$ であったと報告されてい

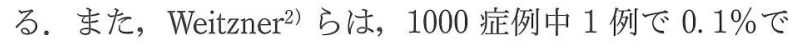


あったとしている。しかし里見ら ${ }^{3)}$ の報告によると，腎 細胞癌の耳鼻咽喉科領域への転移は 64 症例中, 鼻副鼻腔 が最も多く 24 例で, 舌は 3 例で $5 \%$ であり, その数は決 して少なくないと述べている，北尾ら ${ }^{4)}$ は，鼻副鼻腔へ の転移が多いことに対し，耳鼻咽喉科医としては，診断 困難な腫瘍をみつけた場合は，腎細胞癌の転移も念頭に 置いておく必要があると述べている.さらに耳鼻咽喉科 領域の転移から, 腎細胞癌が発見される場合も報告され ている5)ことから,われわれもその必要性を再認識した。

一般に腎細胞癌の舌転移例の予後は悪く, 本邦での報 告でも生存例は少ない3) 9)10). これらの症例の舌転移巣 への治療としては, 全身状態や腫瘍の状態を分析し, 個々 の症例で選択は異なってこよう。本邦では，レーザーな ぞを用いた外科的治療 ${ }^{415)}$, 化学療法 ${ }^{6)}$, 化学療法と放射 線療法の併用 7$)$, などが施行され，比較的局所に関して は制御されることが多いと報告されている5). 本症例は, 舌腫瘤が認められたときはすでに末期状態であったが， QOL 改善を目的として腫瘍摘出術を行った. 術後は咀嚼 障害が改善され，経口摂取も可能となった。 このように， 舌転移に対する治療を考えるうえで舌機能改善を目的と した治療の選択は重要であると思われ，舌への転移病変 が高度な機能あるいは形態障害なしに摘出可能ならば, 一時的な QOL 改善のために外科的摘出は効果的な方法 であり，積極的に行うべきであると考えられた。

本論文の要旨は第 123 回日耳鼻神奈川県地方部会学術講演会 （平成 15 年 3 月 22 日，横浜市）において口演した.

\section{参考文献}

1) Zegarelli DJ, Tsukada $Y$, Greene GW, et al. : Metastatic tumor to the tongue. Oral surg $35: 202 \sim 211,1973$.

2) Weitzner $S$ and Hentel $W:$ Metastatic carcinoma in tongue. Oral surg $25: 278 \sim 281,1968$.

3）里見佳昭, 松浦謙一, 小川 英, 他：腎癌の耳鼻咽喉科領 域 (耳下腺, 鼻腔, 舌, 歯肉) への転移症例. 臨泌 $28: 611$ $\sim 616,1974$.

4）北尾健二郎, 渡辺 敬, 宮村健一郎, 他: 舌根に転移した Grawitz 腫瘍の 1 症例. 耳喉 $58: 67 \sim 70,1986$.

5）石井準之助, 山崎賢一, 吉岡 歩, 他: 舌へ転移を認めた 腎細胞癌の 1 例. 日口外誌 $47: 301 \sim 304,2001$.

6）松本充司, 飯尾昭三: 腎癌舌転移の 1 例. 西日泌尿 49 : $1147 \sim 1149,1987$.

7）稲井 徹, 香川 征, 淡河洋一, 他：舌転移をきたした腎 細胞癌の 1 例. 泌尿紀要 $33: 1240 \sim 1243,1987$.

8）紺屋英児, 原 靖, 梅川 徹, 他: 他臓器転移加ら発見 された腎細胞癌の 2 例. 泌尿紀要 $43: 647 \sim 650,1997$.

9) Ishikawa J, Morisue K, Imanishi O, et al. : Renal cell carcinoma metastic to the tongue: a case report. Hinyokika kiyo $37: 263$ $\sim 265,1991$.

10) Okabe $Y$, Ohoka H, Furukawa $M$, et al. : View from beneath: pathology in focus renal cell carcinoma metastasis to the tongue. J Laryngol Otol $106: 282 \sim 284,1992$.

原稿受付: 平成18年 9 月 6 日 原稿採択 : 平成18年12月15日 別刷請求先 : 田中泰彦 テ225-0025 神奈川県横浜市鉄町2201 横浜総合病院耳鼻咽喉科 